\title{
PERANCANGAN DINAMOMETER SKALA KECIL UNTUK PENGUJIAN KARAKTERISTIK GESEK BAHAN BLOK REM KERETA API
}

\author{
Rizal Akhmad Bukhori ${ }^{1}$, Eko Surojo ${ }^{2}$, Nurul Muhayat ${ }^{3}$ \\ ${ }^{1}$ Mahasiswa S1 Program Studi Teknik Mesin, Fakultas Teknik, Universitas Sebelas Maret, \\ Email: ${ }^{1}$ rizal.akhmed@gmail.com \\ ${ }^{2,3}$ Program Studi Teknik Mesin, Fakultas Teknik, Universitas Sebelas Maret \\ Email: ${ }^{2}$ surojo@ft.uns.ac.id
}

\begin{abstract}
The brake blocks are components of the railway braking system that are useful for reducing speed or stopping the railway. In the development of railway brake block material needs a device that capable of testing the characteristics of the brake block material. One of the important characteristics of the brake block material is the frictional characteristic. The method of testing the frictional characteristics of existing brake blocks include using the pin on disc method, direct testing on the railway and using a full-scale dynamometer. The full-scale dynamometer has advantages than other methods because it can test specimens according to the actual railway braking conditions in a short time and less preparations. However, with the same specimen size as the original, the cost of making the specimen and the full-scale dynamometer become expensive. Therefore, to reduce the cost of making device and test specimens, this study will design the dynamometer small-scale brake block testing. This paper use Pahl and Beitz design method which divides the design into four stages: clarification of the task, conceptual design, embodiment design, and detail design. This dynamometer is designed by considering function designs, structures, and forces that are adapted to the brake block contact pressure according to the original conditions. This dynamometer is designed to vary material, wheel speed, and contact presssure with the output of measurement of friction coefficient of brake block material. Brake block test specimens have a reduced size with a 1: 4 scale from their original size. The results obtained from this research are engineering drawings and dynamometer test model of railway braking.
\end{abstract}

Keywords: railway brake blocks, design, small-scale dynamometer

\section{PENDAHULUAN}

Kereta api merupakan salah satu sarana transportasi yang banyak digunakan di Indonesia. Salah satu bagian penting dari kereta api adalah blok rem. Material yang digunakan sebagai bahan blok rem kereta api di Indonesia adalah metal (besi cor kelabu) dan komposit. Untuk mendapat pengereman yang baik, aman dan biaya yang murah saat ini banyak dikembangkan berbagai macam material untuk pembuatan blok rem kereta api.

Dalam rangka pengembangan diperlukan pengujian terhadap kemampuan material blok rem. Salah satu kemampuan blok rem yang penting adalah karakteristik geseknya. Pengujian karakteristik gesekan blok rem yang ada saat ini diantaranya adalah pengujian dengan pin on 
disc test machine, yaitu sampel spesimen uji digesekkan pada piringan yang berputar (Ferrer et al., 2010). Pengujian ini tidak dapat menggambarkan kondisi sebenarnya saat terjadi pengereman pada kereta api. Metode lain yaitu pengujian langsung pada kereta api yang dijalankan pada rel (Abbasi et al., 2012). Pengujian dilakukan dengan memasang sensor pada rem kereta untuk mengetahui temperatur, perlambatan, gesekan dan gaya penekanan yang terjadi. Metode ini memerlukan biaya yang sangat besar dan persiapan yang rumit. Metode lain yaitu metode pengujian dengan menggunakan dinamometer skala penuh yang dapat menguji karakteristik blok rem dan semua fenomena yang terjadi saat pengereman kereta api (Gerlici \& Harušinec., 2014).

Dari berbagai metode yang telah ada, pengujian menggunakan dinamometer merupakan pengujian yang paling efisien. Metode ini dapat menguji karakteristik blok rem dalam waktu yang singkat sehingga baik digunakan untuk rekayasa material blok rem yang memerlukan banyak pengujian. Akan tetapi metode pengujian dengan dinamometer skala penuh memerlukan biaya pembuatan alat uji dan spesimen yang mahal. Berdasarkan hal tersebut perlu adanya perancangan dan pembuatan dinamometer uji blok rem kereta api dengan ukuran lebih kecil agar dapat menekan biaya pembuatan spesimen uji dan pembuatan alat uji. Oleh karena itu dalam penelitian ini akan dirancang sebuah dinamometer skala kecil untuk pengujian karakteristik bahan blok rem kereta api yang dapat memvariasikan material blok rem, kecepatan putar roda, dan tekanan kontak blok rem dengan roda.

\section{METODE PENELITIAN}

Dalam perancangan ini digunakan metode perancangan Pahl dan Beitz (Pahl \& Beitz., 1996) yang membagi perancangan menjadi empat tahap sebagai berikut:

a. Penjabaran tugas (clarification of the task)

Tahap ini meliputi pengumpulan informasi permasalahan dan kendala yang dihadapi. Pada tahap awal dilakukan studi literatur mengenai perancangan serta pengumpulan data-data untuk kebutuhan perhitungan perancangan alat uji sistem rem yang berasal dari jurnal maupun penelitian terdahulu. Pada tahap ini dijelaskan spesifikasi yang diinginkan pada dinamometer yang akan dibuat.

b. Penentuan konsep rancangan (conceptual design)

Tahap ini diawali dengan menganalisa spesifikasi yang menjadi dasar pembuatan abstraksi dari permasalahan. Tahap berikutnya dilakukan pembuatan struktur fungsi yang menggambarkan hubungan antara input, proses dan output. Pada tahap kedua ini ide rancangan 
diolah dan dikembangkan menjadi beberapa alternatif disain. Alternatif disain tersebut kemudian diberikan penilaian dari segi teknis dan ekonomis untuk memutuskan disain mana yang sesuai dengan tuntutan.

c. Perancangan bentuk (embodiment design)

Tahapan ini dilakukan pembentukan layout awal dan dilanjutkan dengan layout jadi. Pada tahap ini layout awal dikembangkan lebih lanjut dengan menentukan bentuk, material, dan dimensi elemen-elemenya. Pada tahap ini juga dilakukan analisa kekuatan menggunakan software solidwork.

d. Perancangan rinci (detail design)

Pada tahap ini dilakukan pembuatan gambar teknik elemen-elemen yang telah ditentukan bentuknya. Gambar yang dibuat meliputi gambar bagian, gambar assembly, cara manufaktur, cara perakitan dan cara penggunaan dinamometer.

\section{HASIL DAN PEMBAHASAN}

A. Penjabaran tugas (clarification of the task)

Pada tahap ini ditentukan spesifikasi yang dibutuhkan dinamometer agar dapat bekerja sesuai keinginan.

a. Perhitungan gaya tekan blok rem pada roda

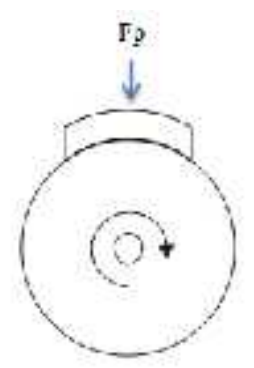

\section{Gambar 1. Gaya Tekan pada Blok Rem}

Gaya tekan yang terjadi pada saat pengereman kereta api sesungguhnya sebesar $6810 \mathrm{~N}$ (Koswara., 2008). Gaya tersebut merupakan gaya yang terjadi pada blok rem dengan ukuran sebenarnya yaitu $320 \mathrm{~mm}$ x $80 \mathrm{~mm}$ atau luas penampang $25.600 \mathrm{~mm}$. Oleh karena itu tekanan yang terjadi pada blok rem yaitu:

$P=\frac{F p}{A b}$

$P=\frac{0810 \mathrm{~N}}{25.600 \mathrm{~mm}^{2}}=0.260 \frac{\mathrm{N}}{\mathrm{mm}^{2}}$ 
Luas penampang blok rem pada dinamometer yang diperkecil dengan skala $1: 4$ adalah 80 $\mathrm{mm}$ x $20 \mathrm{~mm}$ atau $1.600 \mathrm{~mm}^{2}$. Spesimen harus dikenai tekanan yang sama dengan aslinya sebesar $0,266 \mathrm{~N} / \mathrm{mm}^{2}$ sehingga gaya yang diberikan yaitu:

$r p=r \times A b$

$F p=0,200 \frac{\mathrm{lV}}{\mathrm{mm}^{2}} \times 1.000 \mathrm{~mm}^{2}=425,6 \mathrm{~N}$

b. Perhitungan kecepatan putar roda

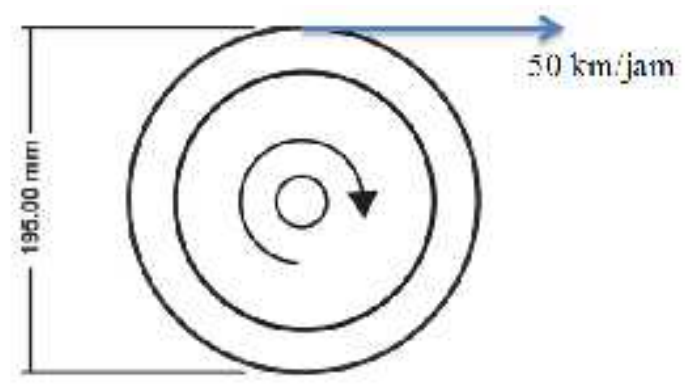

Gambar 2. Kecepatan Tangensial Roda

Kereta api di Indonesia memiliki kecepatan maksimal kurang lebih 100 km/jam akan tetapi pada perancangan ini hanya akan dilakukan pengujian drag braking dengan kecepatan konstan $50 \mathrm{~km} / \mathrm{jam}$. Oleh karena itu simulasi roda pada dinamometer harus mampu berputar dengan kecepatan tangensial $50 \mathrm{~km} / \mathrm{jam}$ atau 13,89 m/s. Oleh karena itu kecepatan putar roda yaitu:

$$
N=\frac{v \times 60}{D \times n}
$$

Keterangan :

$\mathrm{N}$

$=$ Kecepata putar (rpm)

$\mathrm{V} \quad=$ Kecepatan tangensial $(\mathrm{m} / \mathrm{s}) 13,89 \mathrm{~m}$

D = Diameter roda $(\mathrm{m}) 0.195 \mathrm{~m} / \mathrm{s}$

maka

$$
\begin{aligned}
N & =\frac{13,89 \mathrm{~m} / \mathrm{s} \times 60}{0.195 \mathrm{~m} \times u} \\
& =1.301_{1} 10 \mathrm{r} \mu \mathrm{m}
\end{aligned}
$$

Untuk dapat melakukan pengujian drag braking roda harus bisa berputar secara konstan selama proses pengujian. Oleh karena itu komponen penggerak harus memiliki torsi yang besar untuk menahan gaya gesek tanpa mengurangi kecepatan putarnya. Komponen penggerak juga harus dapat divariasikan kecepatan putarnya.

c. Perhitungan gaya gesek rem 


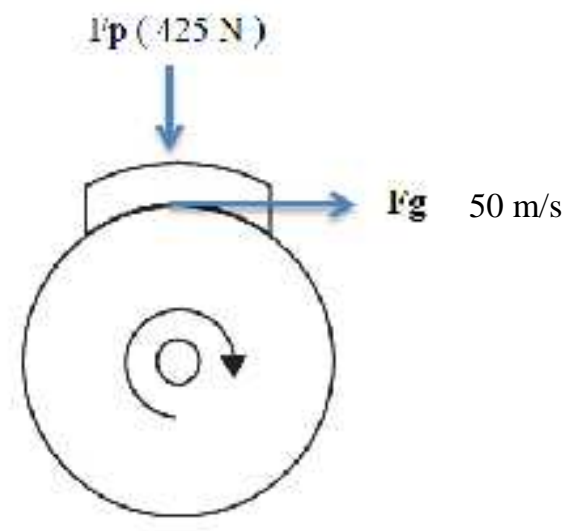

\section{Gambar 3. Gaya Gesek yang Bekerja pada Blok Rem}

Gaya gesek yang bekerja pada blok rem dipengaruhi oleh koefisien gesek rem dan gaya normal atau gaya tekan rem. Dinamometer ini dirancang untuk dapat mengukur gaya gesek hingga 0,48 yaitu koefisien gesek maksimum blok rem komposit tipe K (Vakkalagadda et al, 2015).

$$
r g=\mu \cdot r p
$$

Keterangan :

$\mathrm{Fp}$

$$
=\text { Koefisien gesek rem }
$$

Maka

$F g=0.48 .425 \mathrm{~N}=204 \mathrm{~N}$

d. Perhitungan torsi poros roda

Torsi pada poros roda terjadi akibat putaran yang diberikan komponen pemutar yang ditahan oleh gaya gesek rem saat pengujian.

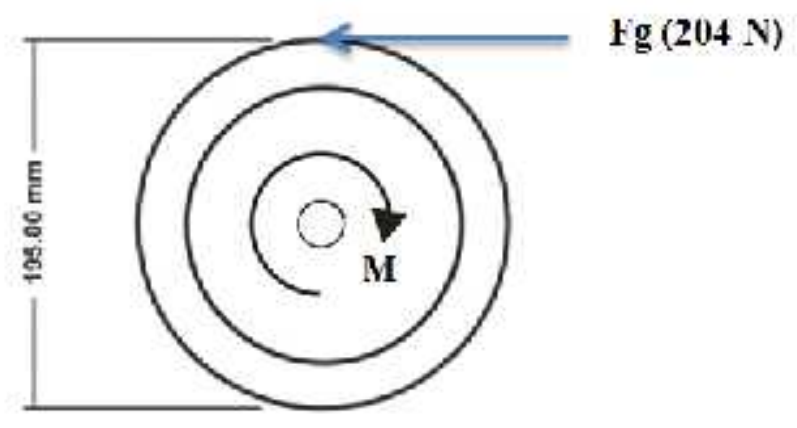

Gambar 4. Torsi yang Bekerja pada Poros Roda

$$
M=r \times F g
$$




$$
\begin{array}{ll}
\text { Keterangan } & \\
\mathrm{M} & =\text { Torsi }(\mathrm{Nm}) \\
\mathrm{r} & =\text { Jari-jari roda }(\mathrm{m}) 0,0975 \mathrm{~m} \\
\mathrm{Fg} & =\text { Gaya gesek rem ( N ) } 204 \mathrm{~N}
\end{array}
$$

Maka

$M=0,0975 m \times 204 m$

$M=19,89 \mathrm{Nm}$

Berdasarkan studi literatur dan kebutuhan maka disusunlah spesifikasi yang harus dipenuhi dinamometer yang akan dibuat sebagai berikut.

1. Bisa mengukur gaya gesek sampai $204 \mathrm{~N}$.

2. Gaya gesek terbaca dan tersimpan dalam komputer.

3. Ukuran blok rem $1: 4$ dari aslinya.

4. Dapat memvariasikan kecepatan putar hingga $1361 \mathrm{rpm}$

5. Dapat memvariasikan gaya penekanan hingga $425 \mathrm{~N}$

6. Terdapat sensor panas.

\section{B. Penentuan konsep rancangan (conceptual design)}

Dari spesifikasi yang telah ditentukan kemudian dibuat konsep atau mekanisme kerja dinamometer yang memenuhi sifat yang diinginkan. Untuk mendapatkan gaya gesek pengereman kereta api perlu dibuat mekanisme yang menggambarkan pengereman sebenarnya pada blok rem kereta.

Untuk dapat memenuhi kebutuhan gaya dan sensor pada dinamometer maka dinamometer dibagi dalam empat bagian utama yaitu bagian mekanisme perputaran roda, bagian penekanan blok rem, bagian sensor serta pembacaan gaya, dan bagian rangka penopang. Dari masing-masing bagian tersebut kemudian dapat ditentukan mekanisme yang diinginkan dan sesuai kebutuhan.

\section{Bagian pemutar roda}

Mekanisme pemutar roda yang akan digunakan adalah menggunakan motor listrik AC 3 fasa sebagaimana ditunjukkan pada Gambar 5. Dengan motor listrik 3 fasa ini kecepatan roda dapat diatur menggunakan inverter dan disesuaikan berdasarkan pengujian yang diinginkan. Untuk mendapatkan torsi yang cukup dan tidak terjadi perlambatan saat pengujian pengereman dibutuhkan motor listrik dengan daya yang besar. 


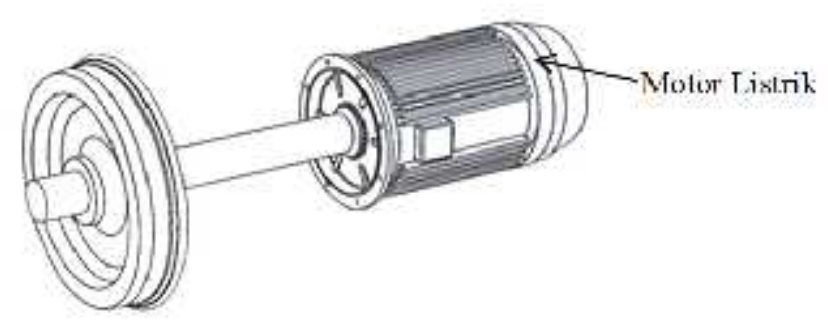

\section{Gambar 5. Konsep Pemutar Roda}

\section{Bagian penekan}

Mekanisme penekanan pada blok rem harus bisa memberikan gaya tekan sebesar $425 \mathrm{~N}$ secara konstan. Gaya yang diberikan juga harus bisa divariasikan. Dalam pembuatan dinamometer ini digunakan mekanisme penekanan manual dengan pembebanan yang dipasang pada sebuah lengan seperti ditunjukkan Gambar 6. Besarnya gaya penekanan dapat divariasikan dengan menambah beban atau menggeser lengan beban. Blok rem yang dijadikan spesimen uji pada dinamometer diperkecil dengan skala $1: 4$ yaitu menjadi $80 \mathrm{~mm}$ x $20 \mathrm{~mm}$.

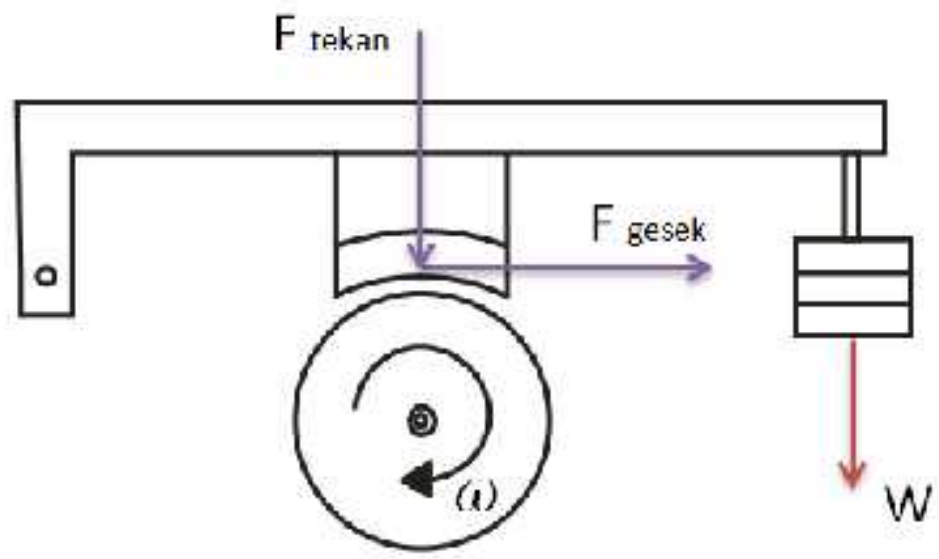

Gambar 6. Konsep Penekan Blok Rem

\section{Bagian pembacaan gaya}

Pembacaan gaya gesek dan temperatur harus dapat dibaca dan disimpan di komputer. Sensor pembaca gaya gesek harus bisa membaca hingga 204 N. Gaya penekanan juga dibaca dengan sensor yang hasilnya ditampilkan di computer untuk memudahkan dan meningkatkan keakuratan pembacaan. Sensor gaya pada dinamometer menggunakan load cell yang ditempatkan segaris dengan gaya gesek. Load cell juga ditempatkan pada penekan blok rem tegak lurus dengan gaya gesek. Sebuah sensor panas inframerah ditempatkan untuk mengukur temperatur roda. Sensor ditempatkan seperti ditunjukkan Gambar 7. 


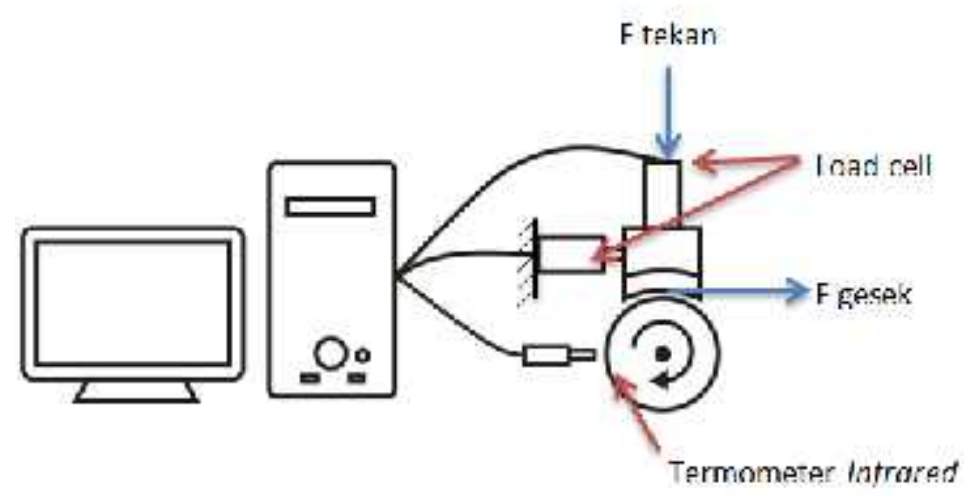

Gambar 7. Konsep Pembaca Gaya

4. Bagian rangka

Rangka yang dibuat harus mampu menopang seluruh bagian dinamometer. Bagian rangka juga harus dapat menjaga poros dan motor listrik agar center. Rangka harus cukup kuat untuk menahan getaran yang terjadi selama proses pengukuran.

C. Perancangan bentuk (embodiment design)

Konsep-konsep dan mekanisme yang telah dipilih kemudian dilakukan analisa terhadap fungsi kerja, kekuatan, dan biaya. Analisa dilakukan untuk menentukan material, dimensi dan pemasangan elemen-elemen dinamometer yang dibuat. Dalam tahap ini dilakukan pembuatan model dinamometer yang dibuat menggunakan software solidwork. Analisa kekuatan juga dikerjakan menggunakan software ini.

1. Bagian pemutar roda

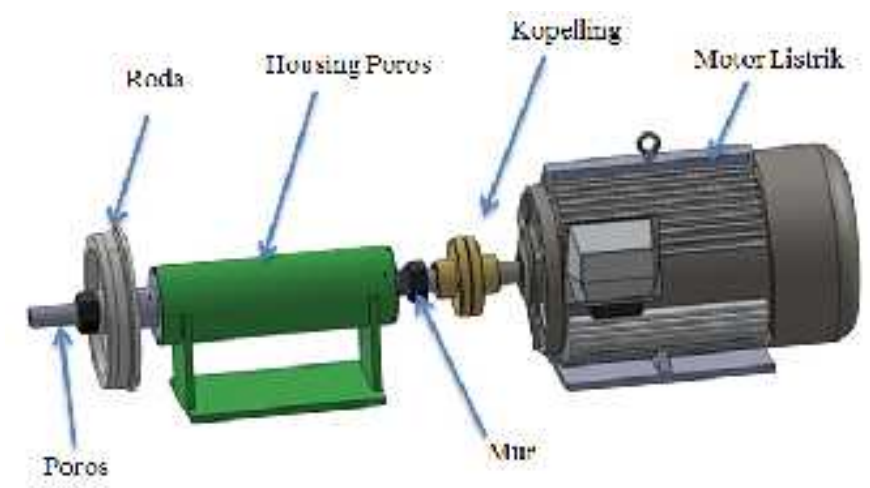

Gambar 8. Perancangan Bentuk Bagian Pemutar Roda 
Gambar 8 menunjukkan bagian-bagian pemutar roda. Walaupun gaya penakanan yang dibutuhkan saat pengujian hanya $425 \mathrm{~N}$ akan tetapi dinamometer ini dirancang untuk mampu menahan tekanan sebesar 750 N. F Gesek merupakan gaya yang dihasilkan dari gesekan blok rem dengan roda kereta. Dinamometer ini didisain untuk mampu mengukur gaya gesek hingga 500 N. Motor listrik yang digunakan adalah motor 3 fasa dengan daya 7,5 PK yang dapat diatur kecepatan putarnya. Bagian pemutar roda ini ditopang rangka pada kaki housing poros dan motor listrik.

2. Bagian penekan

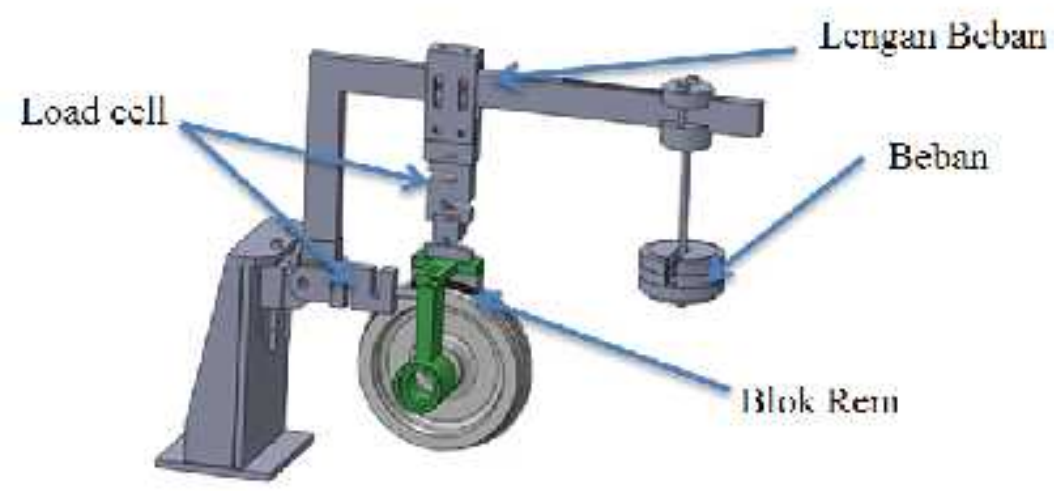

Gambar 9. Komponen Bagian Penekan

Gambar 9 menunjukkan bagian-bagian penekan blok rem. Penekanan yang digunakan pada dinamometer menggunakan mekanisme beban manual dengan lengan pengungkit. Perbandingan panjang lengan pengungkit adalah $1: 2,5$. Beban $\mathrm{W}$ didisain untuk dapat divariasikan sebesar $64 \mathrm{~N}(0,1 \mathrm{MPa}), 106 \mathrm{~N}(0,2 \mathrm{MPa}), 128 \mathrm{~N}(0,26 \mathrm{MPa}), 192 \mathrm{~N}(0,3 \mathrm{MPa})$ dan $256 \mathrm{~N}$ (0,4 Mpa) agar dapat menghasilkan variasi tekanan pada blok rem yang cukup banyak untuk dapat dibandingkan pengaruh tekanannya. Variasi beban dilakukan dengan menambah pemberat pada lengan. Dua buah sensor ditempatkan untuk mengukur gaya tekan dan gaya gesek selama pengujian. Sensor berupa load cell ditempatkan sedemikian rupa sehingga Semua gaya vertikal dan horizontal hanya ditopang oleh load cell saja. Load cell yang digunakan untuk mengukur gaya penekanan dan gaya gesek dapat mengukur hingga 750 $\mathrm{N}$ dan $500 \mathrm{~N}$. 
3. Bagian Rangka

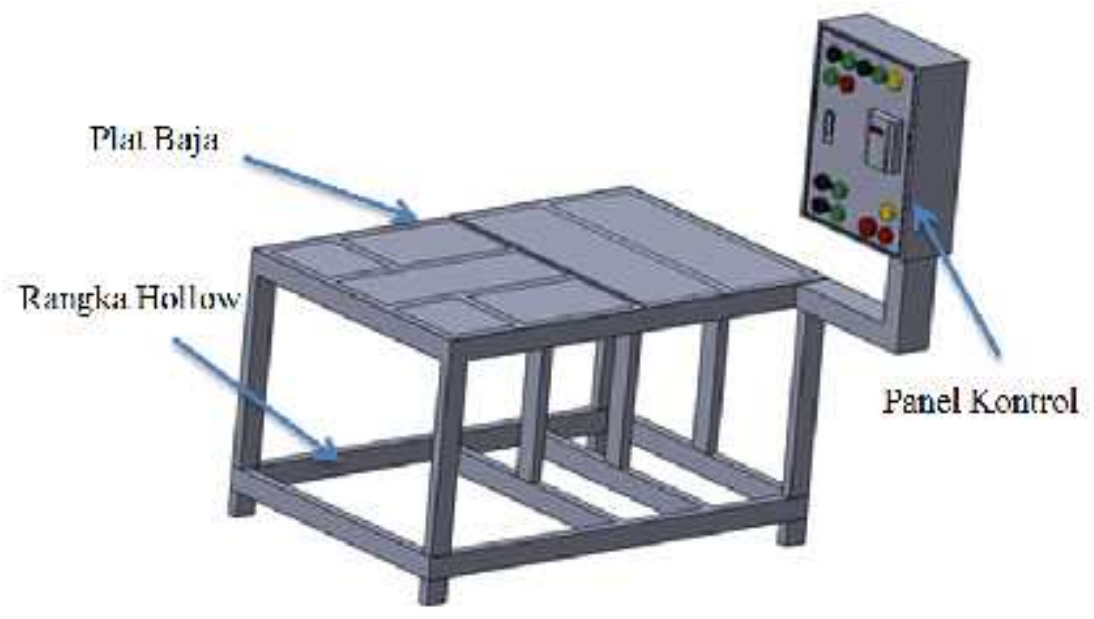

Gambar 10. Komponen Rangka

Gambar 10 menunjukkan bagian-bagian rangka. Rangka dibuat menggunakan baja berongga dengan empat buah kaki. Beban yang ditopang oleh rangka adalah berat dari semua komponen dinamometer. Dalam rangka juga terdapat panel kontrol yang berisi pengatur sensor dan inferter pengatur kecepatan motor listrik.

\section{Simulasi kekuatan}

Dari bentuk dan dimensi yang telah ditentukan kemudian dilakukan simulasi untuk menentukan apakah komponen yang dibuat mengalami kegagalan atau tidak. Simulasi dilakukan pada komponen yang mengalami beban terbesar.

a. Roda

Pada Gambar 11 menunjukkan sebaran tegangan yang terjadi saat pembebanan. Tegangan maksimum yang terjadi sebesar 1,2 MPa.

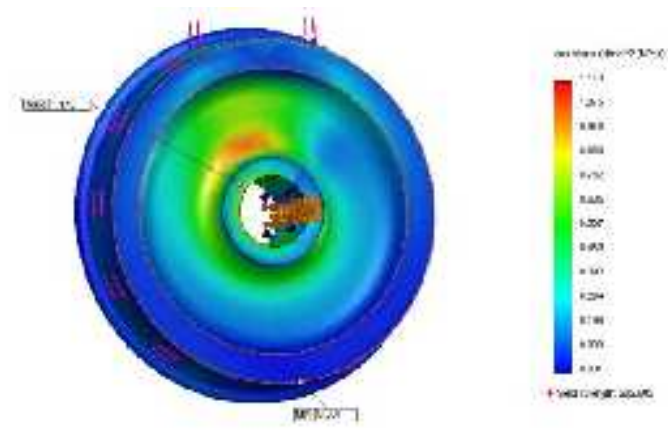

Gambar 11. Tegangan pada Roda 
b. Poros

Pada Gambar 12 menunjukkan sebaran tegangan yang terjadi saat pembebanan. Tegangan maksimum yang terjadi sebesar 36,5 MPa.

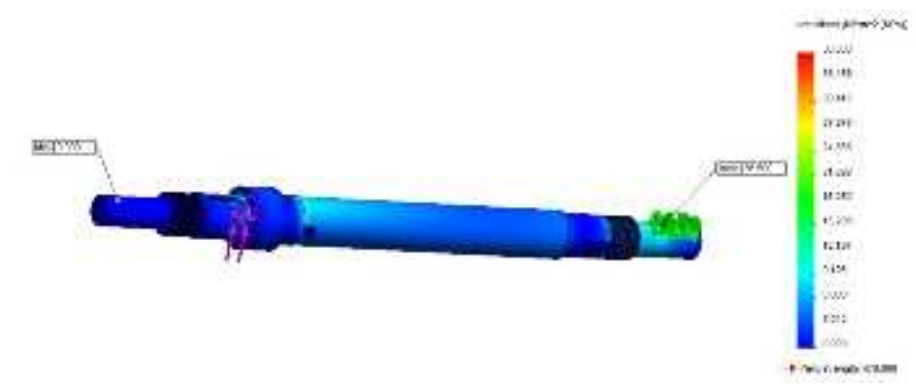

Gambar 12. Tegangan pada Poros

c. Kopling

Pada Gambar 13 menunjukkan sebaran tegangan yang terjadi saat pembebanan. Tegangan maksimum yang terjadi sebesar 3,1 MPa.

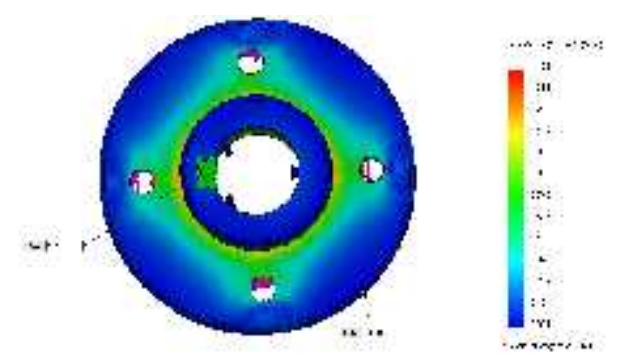

Gambar 13. Tegangan pada Kopling

d. Pasak

Pada Gambar 17 menunjukkan sebaran tegangan yang terjadi saat pembebanan. Tegangan maksimum yang terjadi sebesar 36,9 MPa.

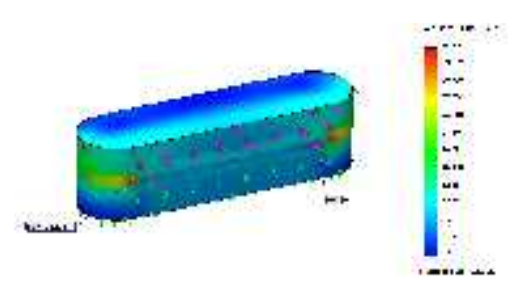

Gambar 14. Tegangan pada Pasak

e. Lever

Pada Gambar 15 menunjukkan sebaran tegangan yang terjadi saat pembebanan. Tegangan maksimum yang terjadi sebesar 69,3 MPa. 


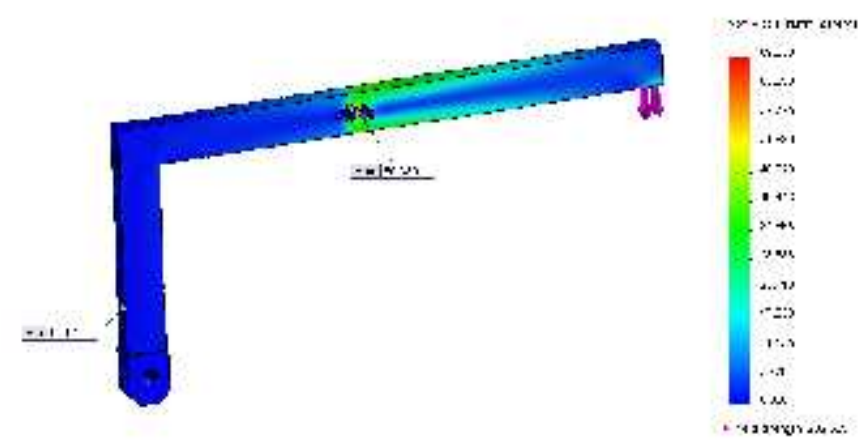

Gambar 15. Tegangan pada Lever

f. Rangka

Pada Gambar 16 menunjukkan sebaran tegangan yang terjadi saat pembebanan. Tegangan maksimum yang terjadi sebesar 5,2 MPa.

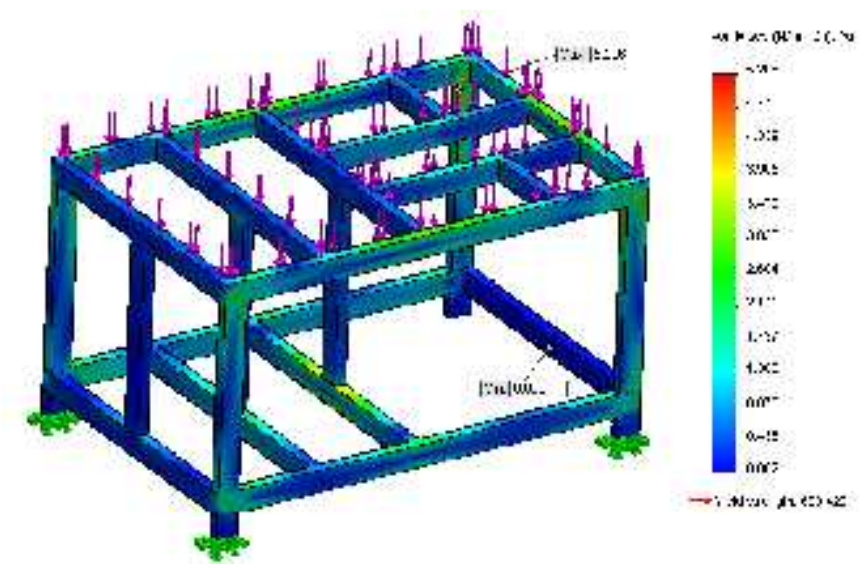

\section{Gambar 16. Tegangan pada Rangka}

Dari simulasi yang dilakukan diketahui bahwa semua komponen dapat menahan bebanbeban yang timbul ketika digunakan.

D. Perancangan Rinci (Detail Design)

Gambar 17 dan Gambar 18 menunjukkan gambar lengkap dan proses perakitan dinamometer. 


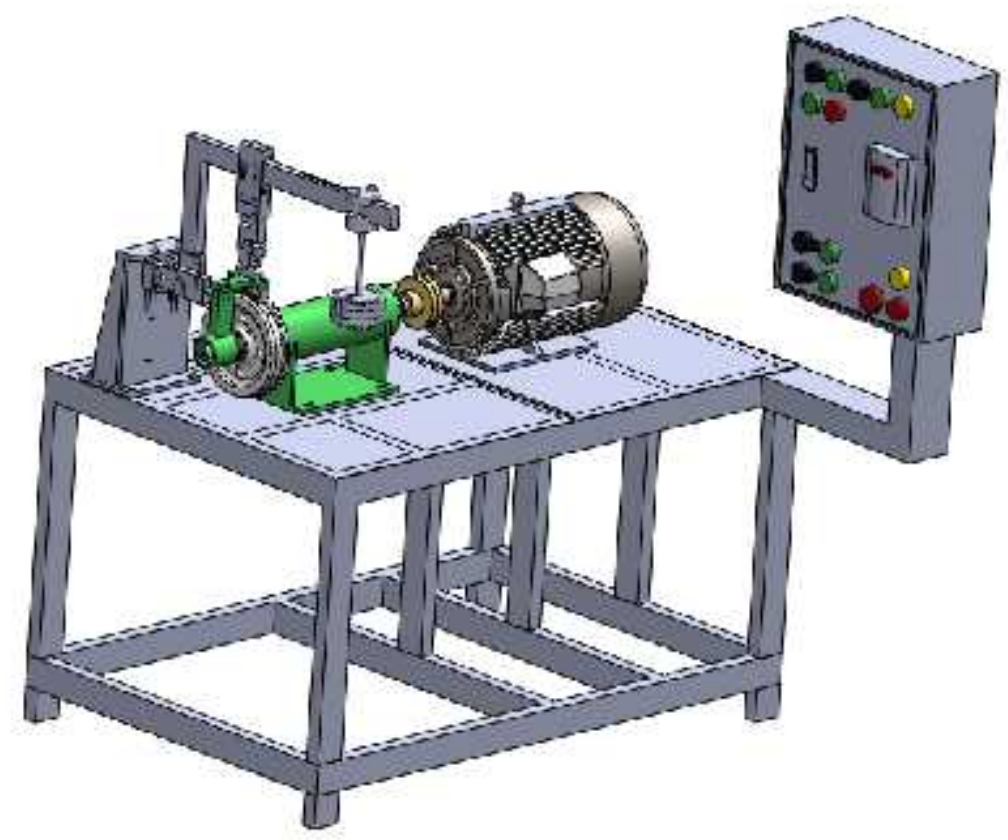

Gambar 17. Disain Dinamometer

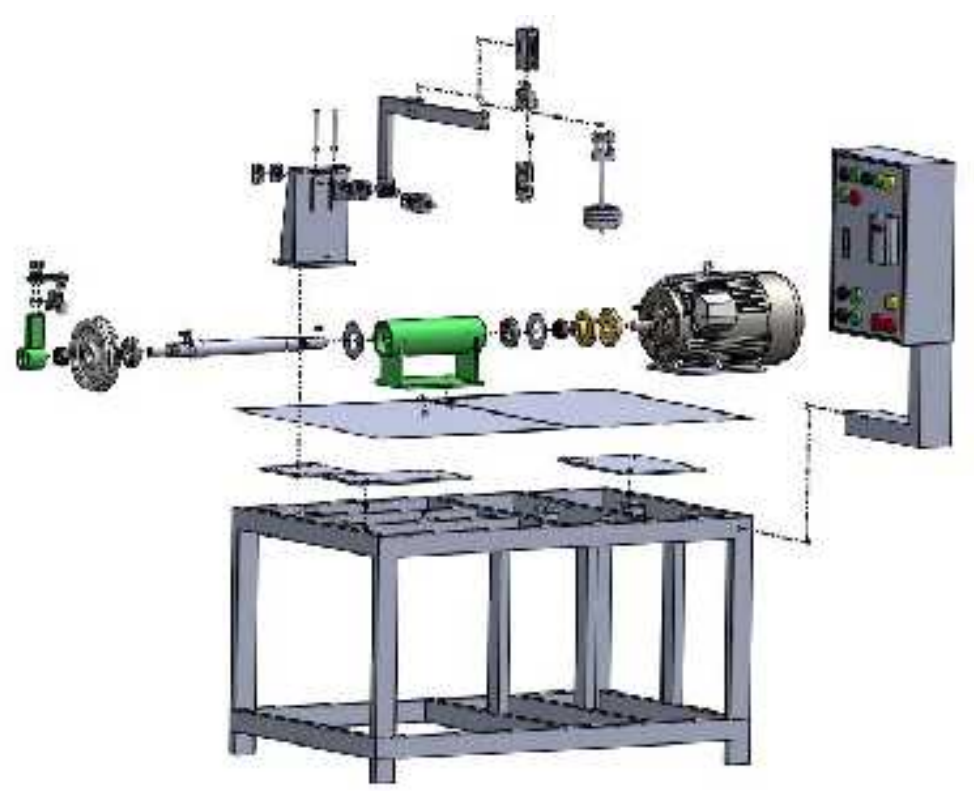

Gambar 18. Proses Assembly Dinamometer

\section{KESIMPULAN}

Dari proses perancangan dinamometer uji pengereman kereta api diperoleh hasil, analisa data - data sebagai berikut:

1. Perancangan dinamometer uji pengereman kereta ini menggunakan blok rem yang diperkecil dengan skala 1:4 dari ukuran blok rem sebenarnya dengan bentuk yang menyerupai kondisi pengereman sebenarnya. 
2. Dinamometer dirancang untuk dapat memvariasikan tekanan kontak hingga $750 \mathrm{~N}$ dan membaca gaya gesek hingga $500 \mathrm{~N}$.

3. Sistem penggerak roda dinamometer menggunakan motor listrik 3 fasa dengan daya 7,5 HP yang bisa diatur kecepatan putarnya. Sensor yang digunakan adalah 2 buah load cell dengan data akuisisi. Dengan analisa, disain dan pemilihan material sudah memenuhi syarat dalam hal keamanan dimana tegangan yang terjadi pada material tiap komponen sistem penggerak, jauh di bawah batas properties atau tegangan maksimum yang mampu diterima oleh material.

4. Gambar susunan dan gambar detail untuk perancangan dinamometer uji pengereman kereta api.

\section{UCAPAN TERIMA KASIH}

Penelitian ini didanai oleh Direktorat Riset dan Pengabdian Masyarakat Direktorat Jenderal Penguatan Riset dan Pengembangan Kementerian Riset, Teknologi, dan Pendidikan Tinggi melalui Skema Penelitian Tim Pascasarjana Pendanaan Tahun 2017, nomor kontrak: 873/UN27.21/PP/2017

\section{DAFTAR PUSTAKA}

Ferrer, C., Pascual, M., Busquets, D., \& Rayon, E. (2010). Tribological study of $\mathrm{Fe}-\mathrm{Cu}-\mathrm{Cr}-$ graphite alloy and cast iron railway brake shoes by pin-on-disc technique. Wear, 268(5), 784789.

Abbasi, S., Olander, L., Larsson, C., Olofsson, U., Jansson, A., \& Sellgren, U. (2012). A field test study of airborne wear particles from a running regional train. Proceedings of the Institution of Mechanical Engineers, Part F: Journal of Rail and Rapid Transit,226(1), 95109.

Gerlici, J., Lack, T., \& Harušinec, J. (2014). Rail vehicles wheels and brake blocks wear laboratory test stand utilization. Prace Naukowe Politechniki Warszawskiej. Transport, (101), 21-32.

Beitz, W., \& Pahl, G. (1996). Engineering design: a systematic approach. MRS BULLETIN, 71.

Koswara, Dedi. Analisis gaya-gaya pengereman sistem udara tekan otomatis pada gerbong kereta api di stasiun besar Purwokerto. (2008).http://docplayer.info/31005483-Bab-ii-sistempengereman-k-ereta-api.html/ Accesed 17.15.08

Vakkalagadda, M. R. K., Srivastava, D. K., Mishra, A., \& Racherla, V. (2015). Performance analyses of brake blocks used by Indian Railways. Wear, 328, 64-76. 